\title{
Developing a Leadership Profiling System for Higher Education Institutions: A Journey
}

Ismie Roha Mohamed Jais, Azian Mohmad Azman, Ahmad Shakirin Zainal Abidin, and Erlane K Ghani

To Link this Article: http://dx.doi.org/10.6007/IJARBSS/v11-i5/9936

DOI:10.6007/IJARBSS/v11-i5/9936

Received: 13 March 2021, Revised: 16 April 2021, Accepted: 31 April 2021

Published Online: 19 May 2021

In-Text Citation: (Jais et al., 2021)

To Cite this Article: Jais, I. R. M., Azman, A. M., Abidin, A. S. Z., \& Ghani, E. K. (2021). Developing a Leadership Profiling System for Higher Education Institutions: A Journey. International Journal of Academic Research in Business and Social Sciences, 11(5), 376-385.

\section{Copyright: (c) 2021 The Author(s)}

Published by Human Resource Management Academic Research Society (www.hrmars.com)

This article is published under the Creative Commons Attribution (CC BY 4.0) license. Anyone may reproduce, distribute, translate and create derivative works of this article (for both commercial and non-commercial purposes), subject to full attribution to the original publication and authors. The full terms of this license may be seen at: http://creativecommons.org/licences/by/4.0/legalcode

Vol. 11, No. 5, 2021, Pg. 376 - 385

Full Terms \& Conditions of access and use can be found at http://hrmars.com/index.php/pages/detail/publication-ethics 


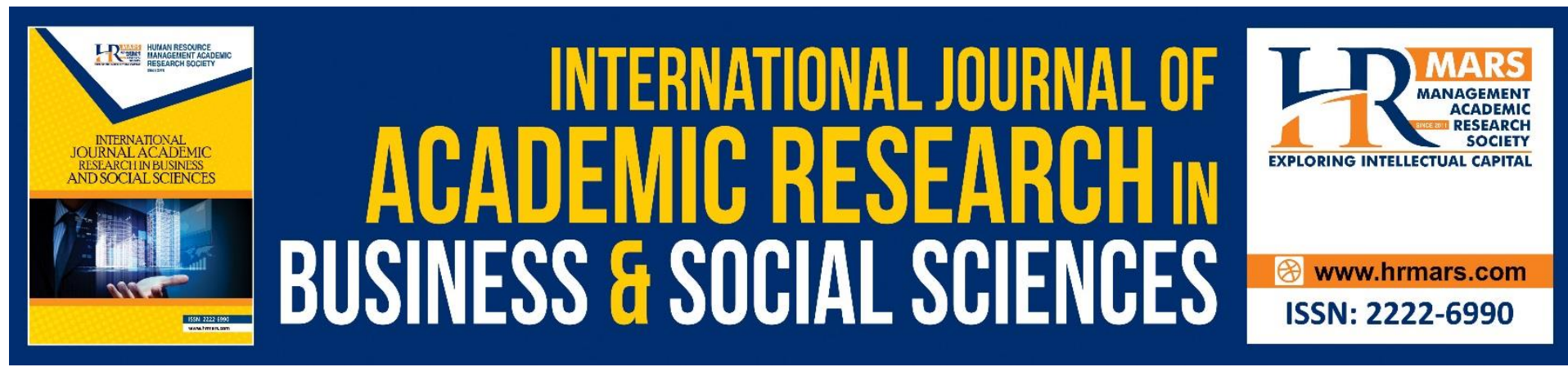

\title{
Developing a Leadership Profiling System for Higher Education Institutions: A Journey
}

\author{
${ }^{1}$ Ismie Roha Mohamed Jais, ${ }^{2}$ Azian Mohmad Azman, ${ }^{3}$ Ahmad \\ Shakirin Zainal Abidin, and ${ }^{4}$ Erlane $\mathrm{K}$ Ghani \\ ${ }^{1,2,3}$ Centre of Leadership Profiling, Akademi Kepimpinan Pendidikan Tinggi, Malaysia, \\ ${ }^{4}$ Faculty of Accountancy, Universiti Teknologi MARA Selangor, Malaysia \\ Email: erlanekg@uitm.edu.my
}

\begin{abstract}
Over the decades, leadership has long been debated due to its importance in an organisation, particularly for higher education institutions. Realising this importance, the Malaysian Ministry of Higher Education had set up a unit, known as Akademi Kepimpinan Pendidikan Tinggi (AKEPT), to be actively involved in leadership talent management for higher education institutions in the country. This paper reports the journey that AKEPT had gone through in developing the leadership profiling system for higher education institutions in Malaysia. This study utilised the content analysis approach on the documents related to the leadership profiling system. This paper reports that AKEPT has made tremendous efforts in ensuring that an effective leadership profiling system is established. It faced several challenges in ensuring that the leadership profiling system can be successfully implemented. The findings in this study are important to ensure leadership excellence in higher education institutions to gauge the leadership competency gaps of potential talents. The profiling system is crucial to execute a more strategic leadership development plan for effective and efficient talent management.
\end{abstract}

Keywords: Leadership, Profiling, Academics, Higher Education, Malaysia

\section{Introduction}

Higher education leadership can be seen as "dynamic, complex, and multidimensional and thus offers numerous opportunities for further investigation due to its constants changes, adjustments, and turbulent environment in the last decade" (Filan \& Seagren, 2003, p.21). The leadership in higher education institutions is often related to the individuals' skills in guiding their peers and subordinates and taking actions to achieve effective and efficient organisational performance. Higher education institutions are perceived to develop and educate tomorrow's leaders who will eventually hold important positions in various organisations (Filho et al., 2020). One of the challenges is that the higher education institutions are perceived to assume a role in adapting and redirecting actions to promote sustainable development, caring about their education system and top management teams, professors, and researchers as sustainable leaders (Ruben \& Gigliotti, 2017).

In the university setting, institutional leadership positions have always been considered temporary appointments for a stipulated period (Mohamed Jais, Yahaya, \& Ghani, 2021). The 
challenge with this arrangement is that the Ministry of Higher Education has to consistently review the profile of academics in selecting a leader to lead a university by considering the academic's competency skills. Leadership competencies are skills and behaviours that contribute to superior performance. A competency-based approach to leadership enables organisations to better identify and develop their next generation of leaders. Leaders must have virtue, the quality of being morally good. However, such considerations are often distracted by the lack of an appropriate leadership competency skills' profiling system. To assist the Ministry of Higher Education in Malaysia, AKEPT was tasked with developing a leadership assessment centre and instrument. In view of this, AKEPT has provided two main components of higher education leadership, namely academic leadership and institutional leadership. However, developing the leadership assessment centre and instrument was not an easy task as AKEPT had to go through several challenges.

This paper reports the development of a profiling system of leadership competency skills for higher education institutions in Malaysia by AKEPT. It provides an understanding of the challenges faced by AKEPT to assist the Ministry of Higher Education in selecting suitable potential leaders in higher education institutions and sustaining organisational culture of excellence in higher education. The remainder of this paper is structured as follows. The following section, Section 2, provides a review of relevant literature and Section 3 outlines the case study. The findings are presented in Section 4. The last section, Section 5, concludes this paper.

\section{Literature Review}

Leadership is considered one of the most observed but least understood phenomena that involve dynamic undertaking that both researchers and practitioners have struggled to make sense of for centuries (Burns, 1978; Ghani \& Jais, 2018; Jais, Yahaya, \& Ghani, 2020). Thus, leadership has long been debated over the decades due to its importance in an organisation. A large body of leadership literature has examined the issue of leadership and, subsequently, derived multiple contexts and frameworks of leadership (Bass, 1998; Bechtel, 2010). These studies examined leaders and their leadership abilities in terms of behaviours, situations, and transformational abilities (Burns, 1978; Yukl, 2002; Bechtel, 2010). Most of these studies suggested that leadership is a competent leader, regardless of the type of organisation. However, there are studies that have suggested that leadership in higher education institutions is different as these institutions present a unique set of leadership challenges (Smith \& Wolverton, 2010; Anderson, 2015). Smith and Wolverton (2010) argued that the members in a higher education institution often operate in an environment that has little supervision but has a powerful voice in significant institutional decisions. Arguably, the conventional definition of leadership may not be relevant to leadership in higher education institutions.

Leadership in higher education institutions has received much attention since the 1980s with the expansion of students' numbers and the globalisation of the education sector (Black, 2015). The leaders in higher education institutions have to identify the best way and approach to lead their organisations (Black, 2015). The leaders would need to retain a balance in the interests of the faculties and the departments and the interests of other stakeholders, such as the students and the government. Like Smith and Wolverton (2010), Filan and Seagren (2003) also noted that the members in a higher education institution have a powerful voice in significant institutional decisions, albeit operating under little supervision. Therefore, the leaders need to balance the interests of the faculties, departments, and other stakeholders. 
For example, Taylor (2005) found that effective leadership in the academic context is a synergy among variable characteristics of the individual, development strategies, academic development role, and institutional context that determined successful practice and leadership in the institutions.

Mohamed Jais et al. (2021) suggested that there is a need to identify potential leaders who possess not only academic leadership but also institutional leadership. Academic leadership relates to scholars who are influential experts in their respective fields and engage in impactful pursuits (Radwan, Ghavifekr, \& Abdul Razak, 2020). It displays the utmost integrity in advancing novel theories and ideas, leading methodological or pedagogical innovation, or spearheading meaningful societal engagement. It encompasses being an exemplar of teaching and learning and research or professional practice while also mentoring (Radwan et al., 2020). On the other hand, institutional leadership refers to the top and middle management in the university who perform management functions and inspire others to realise the university's vision and mission (Filho et al., 2020). It demonstrates managerial capabilities by being flexible, adaptable, strategic, and, most of all, effective. They can inspire others to create, support, and sustain the environments for talent to flourish by combining strategic and managerial talents with holistic human values to promote well-being among students, staff, community, the nation, and humanity.

Studies in leadership literature have suggested that one way to effectively identify a suitable candidate to become a leader is through profiling. Muller and Turner (2010, p.437) suggested that "profiling provides the idiosyncratic combination of behavioural, temperamental, emotional, and mental attributes of a leader, in order to derive a person's particular leadership style. Profiles are often used to relate the profile dimensions of success or failure in a person's leadership position, or alternatively, select or develop managers from the match between existing profiles of successful managers and those of candidates for appointment to management positions." However, profiling is not an easy task as it may require the development of an instrument to assess the competency skills of the potential leaders. Often, the organisation would face challenges in developing such instrument.

\section{The Case Study}

AKEPT is a small unit in the Ministry of Higher Education in Malaysia. This unit was established in 2008 and operates in Putrajaya, Malaysia. The establishment of AKEPT is significant for higher education institutions as it is actively involved in leadership talent management for higher education institutions in the country. Such involvement aligns with the aspiration of the Malaysian Education Blueprint (Higher Education) 2015-2025, which clearly states the need for building competent leaders towards talent excellence. To date, AKEPT is in the process of profiling 494 academics from 20 public universities, polytechnics, and other related higher education agencies. The academics are profiled through the AKEPT Leadership Assessment Centre based on psychometric tests, Behavioural Event Interview (BEI), and Strategic Plan Presentation (SPP) approaches. This profiling task aims to gauge the leadership competency gaps of potential leaders in order to execute a more strategic leadership development plan for effective and efficient talent management.

To achieve the objective of this study, the researchers reviewed documents related to leadership competency as part of the data collection (Tellis, 1997). Specifically, this study reviewed documents relating to AKEPT, including minutes of meetings and transcripts of focus group discussions conducted previously. In addition, this study also reviewed documents relating to the approaches and ways of assessing an individual's leadership competency level. 
Three approaches were examined: the Strategic Plan Presentation, the psychometric tests, and the Behavioural Event Interview. The study also reviewed the Malaysian Education Blueprint and the Pekeliling Perkhidmatan Negara, consistent with the Soft System Methodology developed by Checkland (1981).

\section{Findings}

As mentioned earlier, to achieve its objective, this study utilised content analysis to understand the journey that AKEPT had gone through in developing the leadership profiling system for higher education institutions. It found that, in order to develop a profiling system on leadership competency skills, AKEPT had taken the initiative to create the Elevating Leadership Instrument and Evaluation (ELItE). ELItE is a brain-sharing session intended for working and improving its work processes due to the realisation that the potential leaders or talents are not with AKEPT. The talents are all at the 20 public universities, and AKEPT does not know everybody registered in its system. For instance, the current number of professors in its system is about 3,000. This figure was obtained from the Ministry, and the professors are active professors listed under the Majlis Profesor Negara. AKEPT knows that all these 3,000 professors are in the 20 public universities. However, it has limited information about them and their ecosystem at the moment. Thus, it needs to hold hands with the talent management unit of all public universities. It established a unit in all 20 public universities called either a succession planning unit or talent management unit. In one of the universities, the unit is known as Pelan Warisan. The nature of business of this unit, whatever it is called, is looking into the succession planning for the university.

This study also shows that AKEPT looked specifically into the leadership assessments centre. The package that comes along with it would be the instruments used. In the context of higher education, AKEPT has several other instruments that it had tried, of which a few worked and a few failed and were reviewed. This study found that AKEPT made a lot of quality improvement to be where it is today. The academy is looking into a very engaging session to tap on the elements of leading, impact, and influence. It focuses on the insights of the current instruments that it uses and compares the instruments with the industry to assess whether it is on the right track to obtain this check and balance. For instance, AKEPT has to identify the components or elements that need to be measured for a Chairman of the Board of a university in making or arriving at a decision to renew or terminate an employee. A significant milestone for the education ecosystem for AKEPT at the moment is that it is taking care of 20 public universities in terms of their talent management. The talents would be the number of academics that AKEPT has in its system, which is 31,740 . The total impact to the graduates of about half a million in the total population has to be assessed. This impact would be its main reference for the National Building Agenda in the Eleventh Malaysian Plan. For this agenda, AKEPT has Thrust 3, which is accelerating human capital development for an advanced nation. This thrust is also its primary source of authority in terms of carrying out its functions.

Based on the content analysis of the pertinent documents, this study found that whoever sits as the Director of AKEPT would have a huge role to look into in terms of Shift Two of the Malaysian Education Blueprint 2015-2025, that is talent excellence. There are many listed initiatives under Shift Two, and one of them is preparing the leadership outline, i.e., preparing and strengthening succession planning of higher education institutions. This initiative is part of AKEPT's talent management. Many of Shift Two's initiatives were not there when AKEPT was established. Thus, it started the new initiatives in September 2015, and to date, many things were done despite them being new to the Ministry of Higher Education and 
AKEPT. Therefore, many instruments that were used then were based on a pilot methodology. The academy tried 360, BEI, Leaderless Group Discussion, and others in its leadership competency assessments. It also worked on building a leadership model, which has never been in existence in the Ministry of Higher Education, for evaluation purposes and for scouting talents. That was the year it built and established a leadership model to what it has today.

Another finding in this study is that AKEPT had also managed to build a bank of talent at AKEPT, comprising full professors from the 20 public universities. Going into 2017, it had a large amount of data. During 2015-2016, it had profiled about 287 professors. However, because the academy did not yet have a structured digital system, many things were all on paper. AKEPT had to do a significant amount of data management using excel, visiting operation sites, thinking of how to sustain the whole process, and working on getting an ICT system to support the whole data bank that it had. In 2018, it went into strengthening its leadership assessment centre. The academy was very nervous in 2018 because it had just established the Leadership Cafe, a new initiative to send all the leadership report cards to the individuals. The report cards were necessary because the professors were already giving feedback to AKEPT; they had gone through the assessments but had yet to receive feedback from AKEPT regarding their leadership score. Hence, AKEPT drafted a programme called Leadership Cafe. It invited all the profiled candidates, and the Director of AKEPT handed the individual leadership report cards to the respective professors. This study also found that, in terms of heartbeats, the academy felt pressured at that time because it knew that the professors would come back with literature reviews, question the validity of the instruments, and contest their leadership scores. The leadership assessment instrument was crafted along the way, and AKEPT brought in a human resource partner to establish the Leadership Cafe to explain the whole process of the assessment and the evidence gathered by the assessors to score the leadership competencies. AKEPT believes that its Leadership Cafe is the uniqueness of its higher education ecosystem. It brings in prominent industry or higher education leaders to the sessions in the process of assessing the full professors to transit them into institutional leaders to helm key positions in public universities.

In 2019, it managed to fight for a system at the Ministry of Higher Education. It now has a system known as Unity, which can easily fetch the names of the talents who have been profiled and access the respective candidate's entire profile. In 2015, AKEPT used the Behavioural Event Interview (BEI) and the 360 Evaluation to profile the leadership capability of the potential academic leaders. The BEI measured their competency, and the 360 assessed their integrity, relationship, and performance. The academy naturally had feedback and challenges along the way. AKEPT gathered every single piece of feedback and suggestion that came from the ground. The University community was more than willing to provide feedback, especially on 360. The community would always check with AKEPT whether this information would be treated confidentially at the end of the day and would it impact them in the future in terms of career development. Among the challenges it faced was getting the community members to give genuine responses about the leadership of the universities. Another area was the verification of data. The process of assessing the feedback was very complex since AKEPT received tons of feedback on the 360 evaluations. Since the verifier at AKEPT was none of the university community members, the academy had to go back to the particular university to check every statement made about a professor, its leaders, and others.

From the content analysis of the documents, personal attacks and statements that were not supported by evidence were mostly apparent. Verifying these accusations/statements was a real challenge for AKEPT at that point in time. In 2016, the academy focused on BEI in 
place of the 360. It created the Leaderless Group Discussion (LDG) as part of the assessment process. $\mathrm{BEI}$ is a one-on-one session where the potential leaders sit and discuss with a certified human resource assessor and a prominent higher education assessor assigned from a list of AKEPT assessors. For the LDG, the academics being assessed were put in a group of four to five. They were given a case study within the higher education ecosystem, for instance, the financial sustainability of a university. They were given 30 minutes to prepare the case study and one hour to deliberate on the issue. Among the challenges that AKEPT faced in terms of the LDG was passiveness and dominance. The assessors felt that the professors did well in the BEl. However, when put in a group discussion where there is one prominent or senior professor in the group, the junior professors would remain quiet or became more reserved. This situation is probably due to the work culture at the universities, where the senior professors usually dominate over the junior academics.

From 2017 till today, AKEPT assesses academics who are identified as potential leaders at the centre. It looks at the whole range of talent management or talent succession planning process. It focuses on full professors because it was apparent that academic leadership is very critical when it looked at all the higher or key positions of the 20 public universities. Academic leadership means the potential leaders have to be full professors before transitioning themselves into institutional leadership. Hence, AKEPT studied the demographics of the professors and decided together with the human resource advisor to work on just the BEI, which is the one-on-one session for 2 hours per session. Subsequently, it added another assessment instrument, the strategic paper presentation. Each professor would have to deliberate with 2 panellists, one from higher education and one from human resource, on their plan for the university if they were appointed as the Vice Chancellor or Deputy Vice Chancellor of the university. AKEPT had utilised these instruments for the 2015-2020 leadership assessments since it is dealing with the academic ecosystem.

This study also shows that AKEPT has looked into the instruments' credibility and the standing of all the instruments in existence for human resources. The academy has several tests of human resources, such as personality and psychometric tests. However, when using the $\mathrm{BEI}$, each candidate starts with zero points. AKEPT is very careful with the assessments and keeping the scores because the candidates, especially the participants of the National Taught Talents, could always contest their leadership scores. The academy stands by its scores because it believes that the instrument has an accuracy of 0.61 out of 1.00 . However, AKEPT needed another instrument that the universities may utilise to make up the 0.39 difference. This instrument is mainly to soothe the candidates and to inform them of their academic leadership power. AKEPT hopes that, by adding this instrument, they would understand that the $\mathrm{BEI}$ is for institutional leadership rather than academic leadership.

In 2018, AKEPT put together a group of experts in a committee known as AKEPT Leadership Competency Instrument 2018 and 2019 Committee. This committee deliberated on its competency model, giving inputs on what can be done and what should be removed, including looking into the lifespan of the competency model. The committee was set up to look into the instrument used over the two years only because it mainly looked into the dynamic changes of the higher education system and how the competency model could adapt to these changes. For instance, in the past, universities did not have to worry about financial sustainability. Today, however, financial sustainability is an alarming concern, and it is a major agenda at the Ministry of Higher Education. Thus, after a series of deliberations with several groups in its ELItE platform, AKEPT set up the committee to run through all the findings gathered from 2018 to 2019 before setting its work process of 2021. At the moment, AKEPT 
is under a bit of pressure because all the 20 public universities are waiting on what it would do moving forward. Furthermore, AKEPT believes that it is essential to carry out the assessment process correctly to strengthen the talent management units at the public universities. Currently, these units are using AKEPT's competency model as the dominant model, but AKEPT acknowledges that every university has its specific DNA. Therefore, the universities would use AKEPT's model, but they would have additional competency skills suited to their respective institutional levels. They could then use the revised model as their scouting criteria.

To date, AKEPT is directly involved with only 19 of the 20 public universities. Hence, only the feedback from the 19 universities was documented. Most of the academics from these universities questioned the validity of the assessing instruments, the assessors' identity, and the reason for being chosen for assessment, among others. In addition, many of the university members trusted AKEPT to use a psychometric test. Thus, they wanted to know why the psychometric test was not one of the options for the assessment. This study found that AKEPT initially wanted to use only the psychometric test, and they did use the test for a short period. However, when it dug deeper into one of the responses, it discovered that it was the personal assistant of the professor who answered the questions. This discovery raised doubts on the credibility of the competency of the professors under assessment. Therefore, the psychometric test was shelved because the academy was worried that the candidates would not be sufficiently dedicated to rating themselves for all 326 statements. Regarding the qualification of the assessors, AKEPT was pushed to a corner during the Leadership Cafe, where the candidates asked about the assessment and the qualifications of the assessors. These questions posed a real challenge for AKEPT. From the industry's perspective, the psychometric test and the qualifications of assessors are important because the universities do much head-hunting. For C-Suite leadership, the qualification of the assessors does matter. The universities need assessors from the same circle to evaluate the professors. However, professors evaluating professors would be frustrating for many candidates. Thus, AKEPT provides assurance to the ecosystem that the HR assessors are all third party; they are neutral and would not know any of the professors being assessed. The assessment is valid in the sense that they do not have or bring any perception towards the professors when they come for the assessment.

Another challenge is the verification of data shared during an assessment. For example, data shared during the BEI because it is a one-on-one session. In the document review, it was found that the professors tend to ask who would do the verification. Other questions raised include how the assessor would know that this candidate is giving complete information and is there any information privilege to the university. These questions are why AKEPT retains the BEI documents, which contain a narration of every single competency assessment. For each assessment, AKEPT requires two (2) referees. In case there is any statement that may require further checks, the human resource assessors would verify that respective data with the referees. AKEPT needs to ensure that it continuously improves such that it can be confident of the results it presents at the Search Committee Level.

\section{Conclusion}

This study reports the journey of AKEPT in developing the leadership profiling system for higher education institutions in Malaysia. This study is motivated by the need to understand how AKEPT went through the process of developing the leadership profiling system for higher education institutions. From the content analysis of documents relating to 
the organisation and its leadership profiling system, this study showed that AKEPT had made tremendous efforts in ensuring that a leadership profiling system of 494 academics from 20 public universities, polytechnics, and other related higher education agencies a success. This study showed that AKEPT had formed a committee to assist in developing a profiling system based on a few approaches, namely the psychometric test and the Behavioural Event Interview. However, it has experienced several challenges, such as getting the right people to complete the assessment and verifying the data gathered during the assessment. The findings in this study can serve as a guideline for other institutions interested in developing a leadership profiling system in their respective settings. In addition, this paper provides understanding on possible alternatives to the existing leadership competency framework in sustaining organisational culture of excellence, consistent with the aspiration of the Malaysia Education Blueprint (Higher Education 2015-2025).

\section{References}

Anderson, L. E. (2015), Relationship between leadership, organisational commitment, and intent to stay among junior executives, Walden Dissertation and Doctoral Studies, Walden University.

Black, S. A. (2015), Qualities of effective leadership in higher education, Open Journal of Leadership, 4(2), 54-66

Burns, J. M. (1978). Leadership. New York: Harper \& Rowe

Checkland, P. B. (1981). Systems Thinking, Systems Practice, Wiley, Chichester.

Filan, G. L., \& Seagren, A. T. (2003). Six critical issues for midlevel leadership in postsecondary settings. New Directions for Higher Education 124(1), 21-31

Filho, W. L., Eustachio, J. H. P. P., Caldana, A. C. F., Will, M., Salvia, A. L., Rampasso, I. S., Anholon, R., Platje, J., \& Kovaleva, M. (2020), Sustainability leadership in Higher Education Institutions: An Overview of Challenges, Sustainability, 12(3761), 1-15

Ghani, E. K., \& Mohamed, J. I. (2018). A gap analysis on leadership development course effectiveness in higher education in Malaysia, In N. P. Ololube (Ed.), Encyclopaedia of institutional leadership, policy and management (pp. 67-81). Port Harcourt: Pearl Publications.

Mohamed, J. I., Yahaya, N., \& Ghani, E. K. (2020). Development of a leadership competency framework for higher education institutions in Malaysia. International Journal of Innovation, Creativity and Change, 14(1), 155-169

Muller, R., \& Turner, T. (2010), Leadership competency profiles of successful project managers, International Journal of Project Management, 28(5), 437-448

Radwan, O., Ghavifekr, S., \& Abdul Razak, A. Z. (2020). Can academic leadership competencies have effect on students' cognitive, skill and affective learning outcomes. Journal of Applied Research in Higher Education, In press .Available at: https://doi.org/10.1108/JARHE-05-2020-0144

Radwan, O. A. A., Razak, A. Z. A., \& Ghavifekr, S. (2020). Leadership competencies based on gender differences among academic leaders from the perspectives of faculty members: A scenario from Saudi higher education. International Online Journal of Educational Leadership, 4(1), 18-36

Ruben, B. D., \& Gigliotti, R. A. (2019). Leadership, communication, and social influence: A theory of resonance, activation, and cultivation. Bingley: Emerald Publishing. 
Smith, Z. A., \& Wolverton, M. (2010). Higher education leadership competencies: Quantitatively refining a qualitative model. Journal of Leadership \& Organizational Studies, 17(1), 61-70

Tellis, W. M. (1997). Introduction to Case Study. The Qualitative Report, 3(2), 1-14 